\title{
Pendampingan Ibu Hamil dalam Upaya Peningkatan Status Gizi dan Penurunan Anemia di Kelurahan Metesih Kecamatan Jiwan Kabupaten Madiun
}

\author{
*Yeni Utami, Riska Ratnawati, Kholifa Dwi Wahyuningtyas \\ Program DIII Kebidanan \\ Sekolah Tinggi Ilmu Kesehatan Bhakti Husada Mulia Madiun, Indonesia
}

\begin{abstract}
ABSTRAK
Mortalitas maternal dan neonatal adalah penyebab utama mortalitas di negara-negara berkembang, termasuk Indonesia, dan keduanya bersamasama menyebabkan 2,5-3,4 juta kematian penduduk di negara berkembang, termasuk Indonesia. Sejumlah 40 persen kematian pada ibu hamil berhubungan dengan anemia. Di Indonesia, prevalensi anemia pada ibu hamil dan ibu nifas masih sangat tinggi, yakni 37,1 persen menurut data Riset Kesehatan Dasar. Di negara berkembang, satu dari dua ibu hamil diperkirakan anemia. Anemia menjadi masalah kesehatan berat (severe public health problem), jika prevalensinya lebih dari 40 persen dalam suatu wilayah. Anemia adalah keadaan yang ditandai dengan penurunan kadar hemoglobin, jumlah sel darah merah, dan gangguan dalam pemenuhan kebutuhan oksigen. Pada ibu hamil, keadaan anemia ditandai dengan rendahnya kadar $\mathrm{Hb}$, yaitu kurang dari $11 \mathrm{~g} /$ dl. Pelaksanaan kegiatan pengabdian masyarakat yang digunakan adalah pendampingan ibu hamil, pojok gizi, cek HB pada ibu hamil. Metode yang di gunakan adalah terjun langsung memberikan pelayanan pemeriksaaan $H B$, penyuluhan tentang gizi ibu hamil dan pendampingan pada ibu hamil. Kegiatan pengabdian masyarakat kali ini akan menghasilkan luaran berupa kesadaran ibu hamil untuk rutin melakukan periksa kehamilan dan cek HB secara berkala dan melakukan penyuluhan dan pendampingan pada ibu hamil.
\end{abstract}

\section{PENDAHULUAN}

Mortalitas maternal dan neonatal adalah penyebab utama mortalitas di negaranegara berkembang, termasuk Indonesia, dan keduanya bersamasama menyebabkan 2,5-3,4 juta kematian penduduk di negara berkembang, termasuk Indonesia. Sejumlah 40 persen kematian pada ibu hamil berhubungan dengan anemia. Di Indonesia, prevalensi anemia pada ibu hamil dan ibu nifas masih sangat tinggi, yakni 37,1 persen menurut data Riset Kesehatan Dasar (Riskesdas) 2013.

Di negara berkembang, satu dari dua ibu hamil diperkirakan anemia. Anemia menjadi masalah kesehatan berat (severe public health problem), jika prevalensinya lebih dari 40 persen dalam suatu wilayah. Anemia adalah keadaan yang ditandai dengan penurunan kadar hemoglobin, jumlah sel darah merah, dan gangguan dalam pemenuhan kebutuhan oksigen. Pada ibu hamil, keadaan anemia ditandai dengan rendahnya kadar $\mathrm{Hb}$, yaitu kurang dari $11 \mathrm{~g} / \mathrm{dl}$. Terjadinya anemia disebabkan oleh berbagai faktor.

Faktor risiko terjadinya anemia adalah rendahnya asupan zat besi, absorpsi zat besi yang rendah, yang dapat disebabkan dari konsumsi makanan yang mengandung fitat dan fenol. Selain itu, terjadinya anemia juga disebabkan oleh 
kurang enegi kronis (KEK), umur kehamilan, paritas, status gizi, pola konsumsi dan tingkat kepatuhan mengonsumsi tablet $\mathrm{Fe}$ atau tablet zat besi oleh ibu hamil Pemerintah Indonesia sudah melakukan upaya penanggulangan anemia, di antaranya dengan memberikan TTD pada wanita hamil. Pendistribusian TTD juga telah dilakukan melalui Puskesmas dan Posyandu. Hasil Riskesdas 2010 menunjukkan bahwa 80,7 persen perempuan usia 10-59 tahun telah mendapatkan TTD. Untuk meningkatkan konsumsi TTD, maka diperlukan sistem evaluasi dan monitoring yang dapat dipercaya.

Di Kelurahan Meteseh Kecamatan Jiwan Kabupaten Madiun yang jumlah ibu hamilnya tergolong besar dan mengalami anemia $\pm 30 \%$, maka dalam upaya melaksanakan Tri Dharma Perguruan Tinggi pihak STIKES Bhakti Husada Mulia mengadakan pengabdian masyarakat di Keluahan Meteseh Kecamatan Jiwan Kabupaten Madiun dengan melakukan kegiatan pendampingan ibu hamil, pojok gizi, cek HB.

\section{METODE}

Pengabdian masyarakat ini dilaksanakan di desa Metesih Kecamatan Jiwan Kabupaten Madiun. Program ini di tujukan pada ibu hamil di desa metesih sejumlah 43 ibu hamil. Pelaksanaan kegiatan pengabdian masyarakat yang digunakan adalah melakukan kegiatan pendampingan ibu hamil, pojok gizi, cek HB. Metode yang di gunakan adalah terjun langsung memberikan pelayanan pemeriksaaan $\mathrm{HB}$, penyuluhan tentang gizi ibu hamil dan pendampingan pada ibu hamil.

\section{HASIL DAN PEMBAHASAN}

Kegiatan pengabdian masyarakat yang dilakukan di desa metesih dihadiri oleh 43 ibu hamil. Jenis kegiatannya meliputi : Pemeriksaan ibu hamil: pemeriksaan antropometri (berat badan, lingkar lengan), abdomen (palpasi dan auskultasi), pemberian multivitamin dan penyuluhan kesehatan ibu hamil serta persiapan persalinan, Penyuluhan tentang gizi ibu hamil, Cek HB ibu hamil. Pendampingan : senam hamil.

Hasilnya pelaksanaan kegiatan berjalan dengan lancar, ibu-ibu terlihat antusias dan dari pemeriksaan yang dilakukan pada 43 ibu hamil rata-rata semuanya kondisi janinnya sehat, hanya saja ada $10 \mathrm{ibu}$ hamil yang mengalami anemia ringan. Kemudian dilakukan penyuluhan terkait anemia dan gizi ibu hamil agar tidak berdampak buruk terhadap kesehatan janin yang ada di dalam kandungan. Kemudian bagi ibu-ibu hamil yang tidak mengalami anemia dan kehamilannya tidak ada masalah mengikuti senam hamil dan yang terakhir pemberian tablet Fe untuk semua ibu hamil baik yang anemia maupun yang tidak mengalami anemi. Karena pada ibu hamil harus mengkonsumsi tablet Fe sebanyak 90 tablet selama kehamilannya.

\section{SIMPULAN}

Hasil dari kegiatan pengabdian masyarakt ini sesuai dengan tujuan diadakan kegiatan pendampingan ibu hamil, yaitu dapat meningkatkan gizi ibu hamil dengan penambahan pengetahuan tentang gizi ibu hamil, pemeriksaan kehamilan, dan pemeriksaan Hemoglobin (HB) ibu hamil serta pemberian tablet 
FE pada ibu hamil untuk mencegah dan mendeteksi secara dini terjadinya anemia pada kehamilan.

\section{DAFTAR PUSTAKA}

Lozano R, Naghavi M, and Foreman K.Global and regional mortality from 235 causes of death for 20 age groups in 1990 and 2010: a systematic analysis for the global burden of disease study 2010. Lancet. 2010;15:2095-128.

World Health Organization. Iron deficiency anemia assessment, prevention, and control: a guide for programme managers.Geneva: World Health Organization (WHO), 2001.

Indonesia, Badan Penelitian dan Pengembangan Kesehatan, Kemenkes RI. Laporan riset kesehatan dasar tahun 2013. Jakarta: Badan Penelitian dan Pengembangan Kesehatan, Kemenkes RI,2013.

Stoltzfus RJ, and Michele LD. Guidelines for the use of iron supplements to prevent and treat iron deficiency anemia:International Nutritional Anemia Consultative Group. Washington DC: ILSI Press, 2001.

De Maeyer EM, Dallman P, Gurney JM, Hallberg L, Sood SK, and Srikantia SG. Preventing and controling iron deviciency anemia through primary health care: a guide and health administrators and programme managers. Geneva: World Health Organization (WHO), 1989.

Fatimah S, Hadju V, Bahar B, dan Abdullah Z. Pola konsumsi dan kadar hemoglobin pada ibu hamil di Kabupaten Maros, Sulawesi Selatan. Makara Kesehatan. 2011;15: 31-36.

Hidayah W, dan Anasari T. Hubungan kepatuhan ibu hamil mengonsumsi tablet Fe dengan kejadian anemia di Desa Pageraji Kecamatan Cilongok Kabupaten Banyumas. Jurnal Ilmiah Kebidanan 2012;3:1-13.

Indonesia, Badan Penelitian dan Pengembangan Kesehatan, Kemenkes RI. Laporan riset kesehatan dasar tahun 2010. Penelitian Gizi dan Makanan, Juni 2015 Vol. 38 (1): 71-78 Jakarta: Badan Penelitian dan Pengembangan Kesehatan, Kemenkes RI, 2010.

Broek N. Anaemia and micronutrient deficiencies: reducing maternal death and disability during pregnancy. Br Med Bull. 2003;67:149-160.

Friedman M. Keperawatan keluarga: teori dan praktek, edisi 3. Jakarta: EGC, 1998.

Departemen Kesehatan RI. Pedoman nasional penanggulangan tuberkulosis. Jakarta: Departemen Kesehatan. 2002

Lwanga SK, and Lameshow. Sample size determination in health studies: a practical manual. Geneva: World Health Organization (WHO), 1991. 